\title{
Origin and fate of ice fauna in the Fram Strait and Svalbard area
}

\author{
Carolin E. Arndt ${ }^{1, *}$, Olga Pavlova ${ }^{2}$ \\ ${ }^{1}$ University Centre on Svalbard, PB 156, 9171 Longyearbyen, Norway \\ ${ }^{2}$ Norwegian Polar Institute, 9296 Tromsø, Norway
}

\begin{abstract}
The biomass of arctic sympagic (ice associated) amphipods from multiyear ice sampled in September and October 2002 in the Fram Strait between Greenland and Svalbard was approximately $10 \%$ lower than in previous recordings $\left(0.4 \pm 0.17 \mathrm{~g}\right.$ wet mass $\left.\mathrm{m}^{-2}\right)$. Gammarus wilkitzkii Birula and Apherusa glacialis Hansen were the most numerous species at the 4 ice stations, reaching average densities of $7 \pm 6$ and $4 \pm 3$ ind. $\mathrm{m}^{-2}$, respectively. Along the marginal ice zone, sympagic amphipods are released to the water column and rapidly sink towards the seafloor. Amphipod densities in the surface waters ranged between 0 and 9 ind. $\mathrm{m}^{-2}$ for the 0 to $25 \mathrm{~m}$ water layer and between 0 and 5 ind. $\mathrm{m}^{-2}$ for the 25 to $50 \mathrm{~m}$ water layer. In contrast to our observations in sea ice, the most abundant species in the water beneath the ice was Onisimus glacialis Sars. Laboratory experiments indicated that $O$. glacialis reaches $100 \mathrm{~m}$ water depth within approximately $80 \mathrm{~min}$, and G. wilkitzkii sinks twice as fast. Using hydrographical data, air temperature recordings and simulated trajectories, we estimated the origin and drift route of the investigated ice fields and related their recent and longterm history to our findings. The driving forces for the release of ice amphipods are ice breakup and swell, along with the structural decay of the ice due to intense melting. Comparison of various data sets on the standing stock of sympagic amphipods in the ice north of Svalbard suggests that previous calculations estimating the loss of ice-bound bio-energy in the Fram Strait and Svalbard area are overestimations and apply only to certain climatic regimes. Based on our present understanding of (1) the circulation system and ice drift patterns in the Fram Strait, and (2) the impact of thermo- and hydrodynamics on the sympagic ecosystem along the ice margin, we have identified continental shelves and coastal areas as settling and retention zones for released ice fauna.
\end{abstract}

KEY WORDS: Arctic ice fauna · Sympagic amphipods $\cdot$ Fram Strait $\cdot$ Retention areas $\cdot$ Sinking velocity

Resale or republication not permitted without written consent of the publisher

\section{INTRODUCTION}

Persistent low atmospheric pressure and high air temperatures over the Arctic Ocean, combined with an enhanced inflow of warm Atlantic waters in summer 2002, promoted ice divergence and rapid melt in large parts of the interior ice pack and adjacent waters. The ice extent declined to a record low in September 2002 (Serreze et al. 2003). The consequences of such climatic changes to the environment are potentially serious for the sympagic (ice associated) fauna (e.g. Gradinger 1996, Melnikov et al. 2002). Those ice organisms inhabiting the underside of the ice are the first to be affected by thermo- and hydrodynamic stress.
The amphipod species studied herein, Apherusa glacialis Hansen (Calliopiidae), Gammarus wilkitzkii Birula (Gammaridae), Onisimus nanseni Sars and $O$. glacialis Sars (Lysianassidae), have been identified as autochthonous to the ice ecosystem (Gulliksen \& Lønne 1989). The 4 species inhabit the underside of Arctic sea ice, where they feed, reproduce and release their offspring. Being opportunistic in their feeding strategy, sympagic amphipods are primarily or facultatively detritivorous (Arndt et al. 2005a). G. wilkitzkii and $O$. nanseni supplement their diet with live prey or carcasses (e.g. George \& Paul 1970, Scott et al. 1999), whereas A. glacialis and O. glacialis are more herbivorous (e.g. Bradstreet \& Cross 1982, Poltermann 2001). 
G. wilkitzkii has the longest life span among the sympagic amphipods, living up to 6 yr (Poltermann 1997, Beuchel \& Lønne 2002). For the other amphipod species, life spans range between 2 yr (A. glacialis; Beuchel \& Lønne 2002) and 3 to $4 \mathrm{yr}(O$. nanseni and $O$. glacialis, respectively; Arndt \& Beuchel 2005). As far as we know, all species feature a relatively high reproductive potential. Maximal fecundity is in A. glacialis, with over 550 eggs per female life span (Poltermann 1997), followed by G. wilkitzkii with 300 to 500 eggs per female life span (Poltermann et al. 2000). As a long living species of high individual biomass (over $75 \mathrm{mg}$ dry mass) and a mature body length of over $5 \mathrm{~cm}$ (Beuchel \& Lønne 2002), G. wilkitzkii in particular represents an appropriate food source for higher trophic level predators such as polar cod, seals and sea birds (e.g. Bradstreet \& Cross 1982, Gulliksen \& Lønne 1989).

The average abundance value of ice amphipods is 150 ind. $\mathrm{m}^{-2}$ (equivalent to 5 to $6 \mathrm{~g}$ wet mass $\mathrm{m}^{-2}$; Arndt \& Lønne 2002) in the permanent ice pack in the Northern Barents Sea, but ranges can be broad (0 to 500 ind. $\mathrm{m}^{-2}$ ). There are often considerable differences between neighboring ice floes with respect to species composition, density and biomass (e.g. Poltermann 1997, Swadling et al. 1997, Hop et al. 2000), but patchiness can also be found on much smaller scales. Mesoand microscale features such as under-ice topography (Melnikov 1997, Hop et al. 2000) and brine system structure (Poltermann 1998) are the key factors for the amphipods' spatial heterogeneity since they determine the distribution of food and shelter. Multiyear ice that has survived at least 2 summer melts and first-year ice floes within the permanent sea ice cover show higher abundances and biomasses than ice within the seasonally ice covered regions (Arndt \& Lønne 2002). Occasionally, sympagic amphipods leave the ice for short excursions into the ice-water interface and, apart from being relocated with their drifting platform for thousands of kilometers, they colonize new ice (Arndt \& Lønne 2002). In contrast to sympagic 'infauna' (Gradinger et al. 1999), some motility allows ice amphipods to escape and seek better living conditions. The swimming ability apparently differs from species to species (Lønne \& Gulliksen 1991a). It is thus likely that the disruption of the habitat during ice melt affects the 4 amphipod species in different ways.

The Transpolar Drift Stream is a conveyor belt for Arctic sea ice towards the large thawing areas south of Fram Strait between Greenland and Svalbard. On an annual basis, about $16 \%$ of the total ice cover leaves the Arctic Ocean through this area (Vinje 2001). The ice in the Fram Strait originates from the eastern (Siberian) and central Arctic (Beaufort Sea) and is composed of first-year and old ice in equal proportions
(Thomas et al. 1996). The oceanic area between Svalbard and Greenland (northern Barents Sea and Greenland Sea) is often referred to as the shear zone between polar and Atlantic regimes (Peinert et al. 2001b) in regard to the origin of water masses (Schäfer et al. 2001) and the distribution of sea ice (Wadhams 2000, Ramseier et al. 2001). This shear zone is generally considered as the major sink of ice-bound biomass (Peinert et al. 2001a, Ramseier et al. 2001). On its passage towards Fram Strait, sea ice encounters a strong salinity and temperature gradient, and consequently continuous melting takes place along the ice edge. In addition to the typical 'bottom melt' during winter, sea ice is subjected to considerable 'surface melt' due to elevated air temperatures in the summer period (Ramseier et al. 2001). A broad belt along the ice margin is further subjected to hydrodynamic forces on different scales, such as swell, breakup, eddies and meanders (e.g. Nøst \& Dybesland 1997), which all contribute to the deterioration of sea ice.

Ice characterization at the sampling site reflects a 'snap shot' of a highly variable and complex system. This study is a first approach to relate the current status of the sympagic community to the history of the ice and its ecosystem. By using simulated trajectories of the ice motion we estimated the drift route of the ice pack before it entered the study area. Knowledge of the presumed origin and history of ice (freeze-melt cycle, residence time in different areas and water masses, age, etc.) provides information on the presumed physical stresses to which the ice ecosystem was subjected prior to sampling. This formed the basis for an analysis of the origin and fate of the ice fauna in space and time. The pelagic occurrence of ice amphipods has been observed previously (Steele \& Steele 1974, Werner et al. 1999). This study, however, presents the first quantitative sampling of sympagic amphipods released to the pelagic realm in an area that has been referred to as the major sink of sympagic fauna (Lønne \& Gulliksen 1991b). The samples were taken in September and October 2002 along the approx. $1000 \mathrm{~nm}$ nautical mile-long fringe of the retreated ice pack in the Fram Strait. Fjords and straits of Svalbard and Greenland were used as reference locations, as some of them are characterized by local ice formation (and should therefore be free of sympagic amphipods throughout the water column) and others are regularly impacted by old ice (and hence contain ice fauna) originating from the central Arctic. A comparison of drift patterns, thermodynamics and hydrography is used to describe our results regarding ice fauna occurrences in the sea ice and the underlying surface water. The objectives of this study were 2 -fold: (1) to quantify the loss of ice amphipods when the ice retreats; and (2) to identify the physical processes 
involved in the evolution and deterioration of the ice habitat on different temporal and spatial scales. Although in part speculative, this study addresses the following issues: (1) ecosystem disruption and mechanisms of release; (2) localization of pelagic occurrence and settling; (3) climatic cycling and loss of sympagic fauna.

\section{MATERIALS AND METHODS}

Sampling. Sampling was conducted in the area $\mathrm{N}$ and NW of Svalbard in the period 12 to 20 Septem- ber 2002 (September samples marked with asterisk in Fig. 1), and in the Fram Strait in the period 27 September to 14 October 2002. In September 2002 the marginal ice zone in the area $\mathrm{N}$ and NE of Svalbard was not well defined, but consisted of relatively small ice floes of varying thickness (mainly 1 to $2 \mathrm{~m}$, but $>2 \mathrm{~m}$ at Stns Ice $\mathrm{E}$ and Ice W). Most of the ice showed characteristics of intense thawing such as widened holes and channels and could be classified as perennial ice that had survived the last 2 summer melts. A sharply defined ice edge, with concentrations of $>40 \%$, existed $\mathrm{NE}$ of Svalbard at $82^{\circ} \mathrm{N}$ and stretched down to $77^{\circ} \mathrm{N}$ on the east coast of Green-

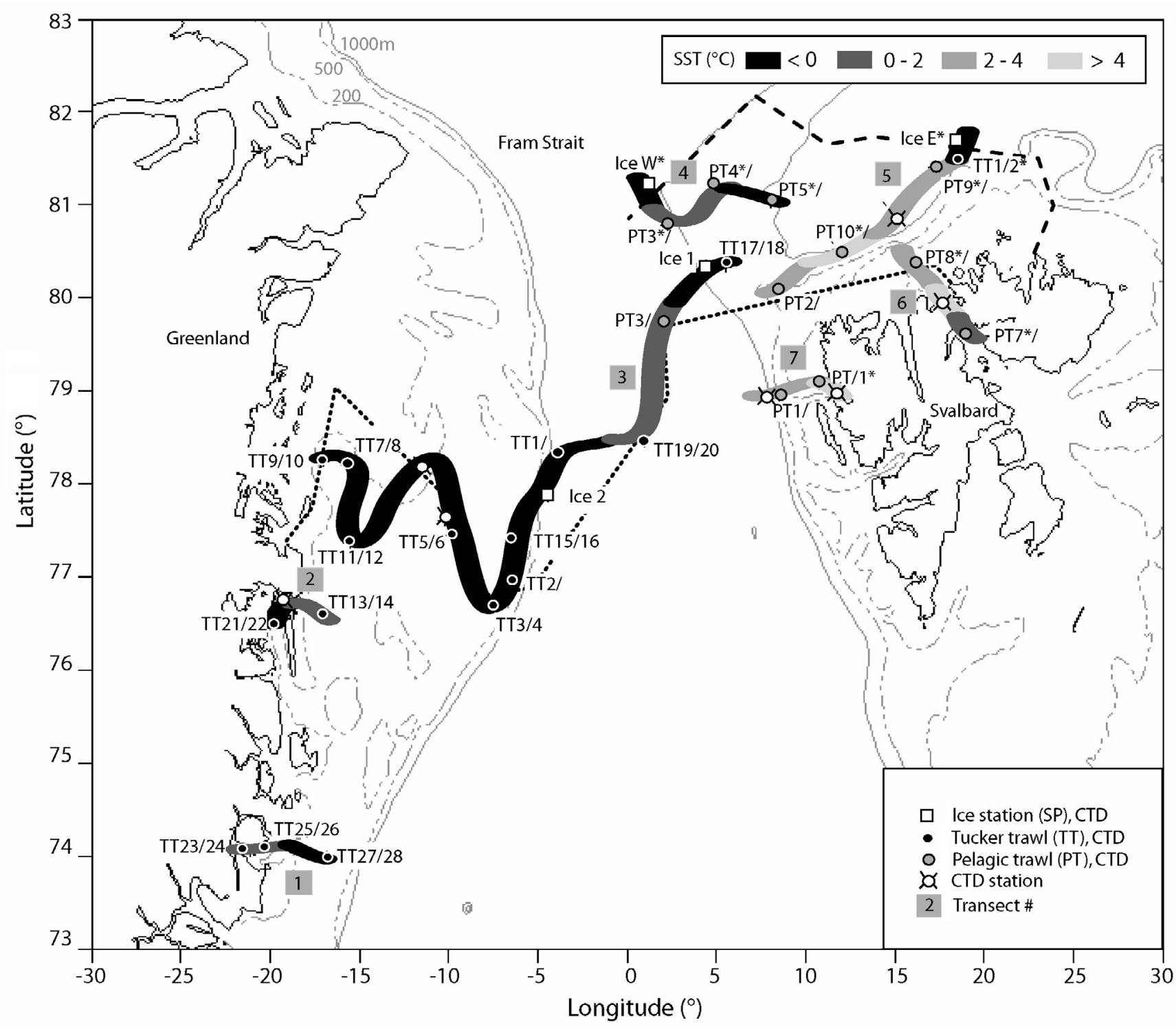

Fig. 1. Bathymetric map of stations (under-ice dives, trawl hauls and additional CTD casts) along 7 transects; shading along transects indicates sea surface temperature, SST (see upper key) integrated over upper 0 to $15 \mathrm{~m}$. (*) September samples. Codes show trawl type (lower key) and haul depth (shallow/deep); e.g. TT 7/8 = Tucker trawl 7 at $15 \mathrm{~m}$ and Trawl 8 at $50 \mathrm{~m}$. PT: pelagic trawl. Ice edge with concentrations higher than $40 \%$ is shown for September (dashed line) and October (dotted line) (data from NSIDC) 
land, leaving the eastern and central Fram Strait ice free (Fig. 1). The ice pack moved southward in a sudden pulse during the first week of October 2002 and filled the area N and NW of Svalbard down to $80^{\circ} \mathrm{N}$ with decaying ice. The proportion of ridged and rafted multiyear ice increased towards the western Fram Strait, but showed similar features of decay. Stns Ice 1 and Ice 2 (Fig. 2) were on 3 and $6 \mathrm{~m}$ thick floes, respectively. Sampling locations were either within or in sight of the ice edge, which we defined in situ as a broad belt of loose ice floes between open water and consolidated pack ice. Additional sampling was conducted in the pelagic of ice-free fjords in Svalbard and Greenland. These fjords are open, allowing, to a certain degree, water and ice to exchange with the outside areas. Each fjord has its individual character, as ice is also produced locally. In particular, the Kongsfjord on the western coast of Svalbard (eastern end of Transect 7 in Fig. 1) proved a good reference fjord, since it is rarely influenced by ice from the central Arctic ice pack.

Ice fauna was collected quantitatively in the ice using a diver-operated suction sampler and in the water column using 2 different trawls: a Tucker trawl (TT), with a rectangular opening of $1 \times 1 \mathrm{~m}$ and mesh size of $1 \mathrm{~mm}$; and a Harstad pelagic trawl (PT), with an ellipsoid opening of $9.5 \times 18 \mathrm{~m}$ and a mesh size that varies with the speed of towing (theoretically the net collects all organisms irrespective of body size; R. Larsen pers. comm.). The preferred sampling depths were 15 and $50 \mathrm{~m}$. To allow for comparison with the sympagic data, the volume trawled was converted into areal units $\left(\mathrm{m}^{2}\right)$ by assuming that the shallow trawl sampled the upper water layer from 0 to $25 \mathrm{~m}$ depth, and the deep trawl collected from the 25 to $50 \mathrm{~m}$ depth layer. The volume trawled was between 1000 and $2000 \mathrm{~m}^{3}$ for the TT and approximately $12000 \mathrm{~m}^{3}$ for the PT samples.

In situ ice-logs on ice conditions and floe characteristics were supplemented by ice charts provided by the National Snow and Ice Data Center (NSIDC), Boulder, Colorado. Under-ice samples were taken from thick multiyear ice. SCUBA-divers used an electric suction pump (SP) with a collector of $500 \mu \mathrm{m}$ mesh size for under-ice sampling and collected all ice amphipods inside an area covered by a floating frame of $0.25 \mathrm{~m}^{2}$; 5 to 10 frames were sampled per station (i.e. per ice floe).

Each ice amphipod sampled in the ice or the water column was sexed and the dorsal length of the 1st pereonal segment (Ls) was measured (Beuchel \& Lønne 2002). The relationship between Ls and total body length $(\mathrm{Lt})$ is $\mathrm{Ls}=\mathrm{Lt} /(19.49+1.62)$ for Apherusa glacialis and Gammarus wilkitzkii (Beuchel \& Lønne 2002) and $\mathrm{Ls}=\mathrm{Lt} /(19.52-0.27)$ for both Onisimus species (Arndt \& Beuchel 2005). The samples were stored frozen for later biomass determination.

Water masses and ice conditions. Temperature and density profiles were measured at each location down to $100 \mathrm{~m}$ water depth using a CTD sensor (Seabird 911 plus). Additional CTD casts were taken between stations. All stations were aligned on 7 transects to generate cross-sections of temperature and density profiles.

The 7 CTD profiles (Fig. 2) reflect a water mass distribution typical for the Fram Strait and Svalbard area (Aagaard et al. 1985). The Greenland shelf surface water (Transects 1 and 2 and the western part of Transect 3) is cold, low saline polar water $\left(<0^{\circ} \mathrm{C}\right.$, salinity $<34.4$ ). This water mass is an extension of the southward moving Transpolar Drift Stream known as the East Greenland Current. The polar water meets the Atlantic province at the Greenland shelf slope and forms a 10 to $20 \mathrm{~m}$ thick freshwater lens at the surface. The Atlantic water signature $\left(>2^{\circ} \mathrm{C}\right.$, salinities $>34.9$ ) can be traced on the shelf W and NW of Svalbard, where it fills the fjords and straits with relatively warm, dense water (Transect 7 , Kongsfjord; and Transect 6, Hinlopen Strait). On its way into the ice covered Arctic basin the Atlantic water mixes with the cold and fresh polar water, but its core remains detectable at greater depths. The warm water inflow can be traced west of the Yermak Plateau (eastern part of Transect 4). The Atlantic water meets the ice edge NE of Svalbard and promotes strong melting of the ice, resulting in a conspicuous drop in density down to at least $100 \mathrm{~m}$ at Stn Ice E (Transect 5).

Sea surface temperatures (SST, Fig. 1) roughly coincide with the extent of the Atlantic and polar water regimes. The combined temperature and salinity data indicate melting conditions at the 4 ice stations: SST at Stn Ice $1,-0.1^{\circ} \mathrm{C}$; at Stn Ice $2,-1.7^{\circ} \mathrm{C}$ (salinity 31.1 ); Stn Ice $\mathrm{W},-1.7^{\circ} \mathrm{C}$ (salinity 31.2 ); and at Stn Ice $\mathrm{E}, 1.8^{\circ} \mathrm{C}$.

Ice drift simulation. The backtracks of the approximate drift route of the individual ice stations were calculated based on the monthly averaged motion vectors derived from satellite data (SSMR and SSM/I data from NSIDC). For the calculation, the annual cycle of the monthly mean vectors of ice drift was averaged for the 17 yr observations between 1979 and 1996. Location and sampling date were set as the starting point for each individual trajectory. The positions backward in time were interpolated from the velocity of one monthly ice motion field to the next. The air temperature at sea level for the period prior to sampling (National Center for Atmospheric Research, NCAR, Boulder, Colorado) was used to mark the freeze-melt cycle on the trajectories for the year 2002. 


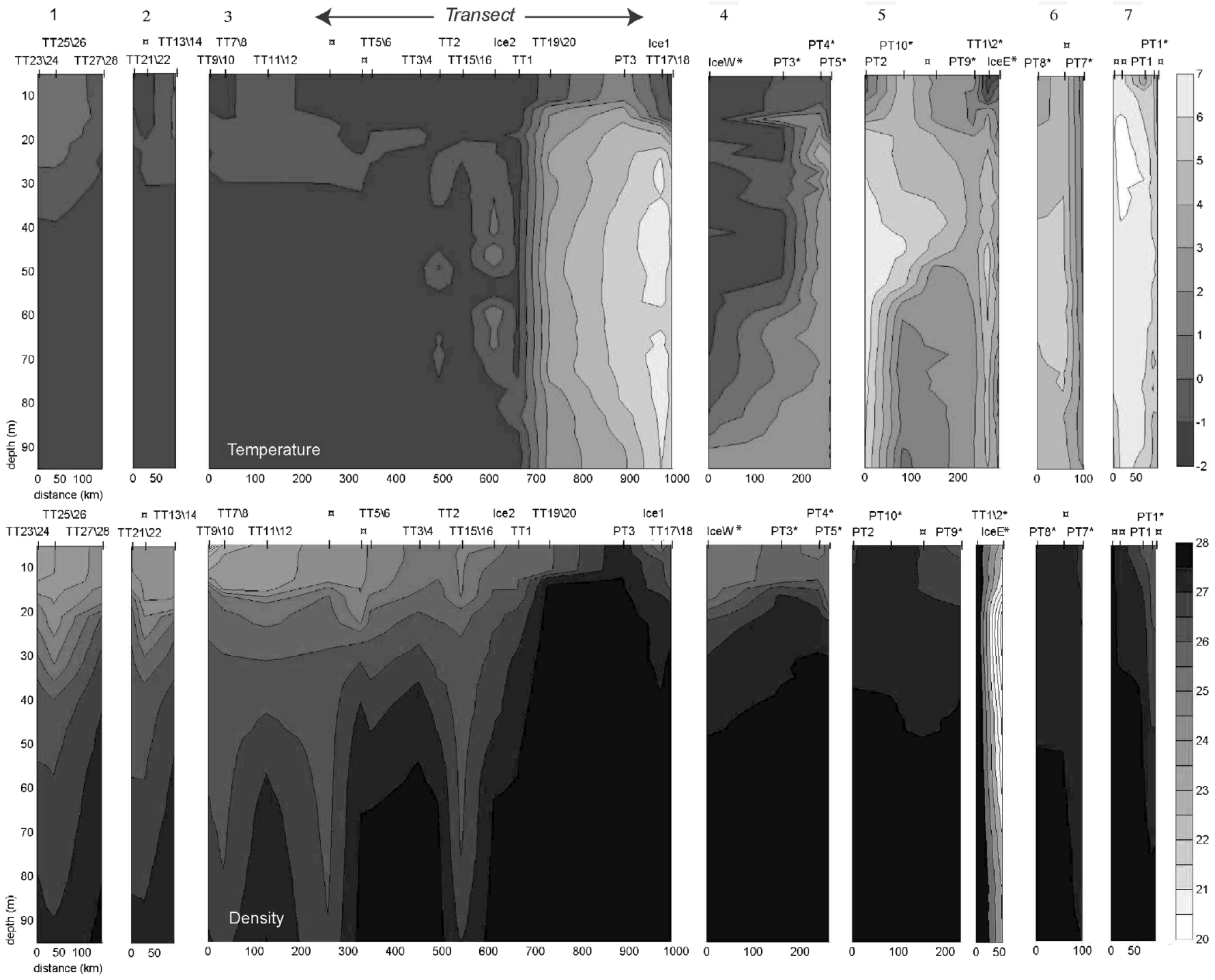

Fig. 2. CTD sections on temperature $\left({ }^{\circ} \mathrm{C}\right.$, top graph) and density $(\sigma \theta$, bottom graph) for the 7 transects in Fig. 1. Station codes and asterisks as in Fig. $1 ;(\mathbb{r})$ additional CTD stations

\section{RESULTS}

\section{Under ice sampling}

In September, amphipod densities at the Stns Ice E and Stn Ice W were on average 11 ind. $\mathrm{m}^{-2}$, but standard deviations were high for Stn Ice W $\left( \pm 14\right.$ ind. $\left.\mathrm{m}^{-2}\right)$. Stn Ice E was the only location at which all 4 sympagic amphipod species were present. The large ice floe studied at Stn Ice 1 in early October showed twice as high abundances $\left(24 \pm 7\right.$ ind $\mathrm{m}^{-2}$ ), but consisted of 2 species (Apherusa glacialis and Gammarus wilkitzkii) only.

Gammarus wilkitzkii dominated the overall sympagic community, with a total of 333 individuals compared to 189 individuals of Apherusa glacialis. For all 4 ice stations combined, these 2 amphipod species reached average densities of $7 \pm 6 \mathrm{SD}$ and $4 \pm 3 \mathrm{SD}$ ind. $\mathrm{m}^{-2}$, respectively. At Stn Ice 2 (at the tip of the October ice tongue) only single individuals of G. wilkitzkii and Onisimus nanseni were recorded.

Of the Gammarus wilkitzkii, $63 \%$ were juveniles and the remainder was comprised almost equally of both sexes (see Fig. 4). Juveniles accounted for half the Apherusa glacialis sampled; the other half consisted of females; males were almost absent. In the Onisimus glacialis samples, females accounted for $46 \%$; of the 50 O. nanseni individuals sampled, $51 \%$ were males.

\section{Trawl sampling}

The trawl catches contained between 0 and 8 ind. $10 \mathrm{~m}^{-2}$ (Fig. 3). Of the shallow Tucker trawls $(\mathrm{N}=30)$, $25 \%$ were empty, and only 6 of 10 shallow pelagic 


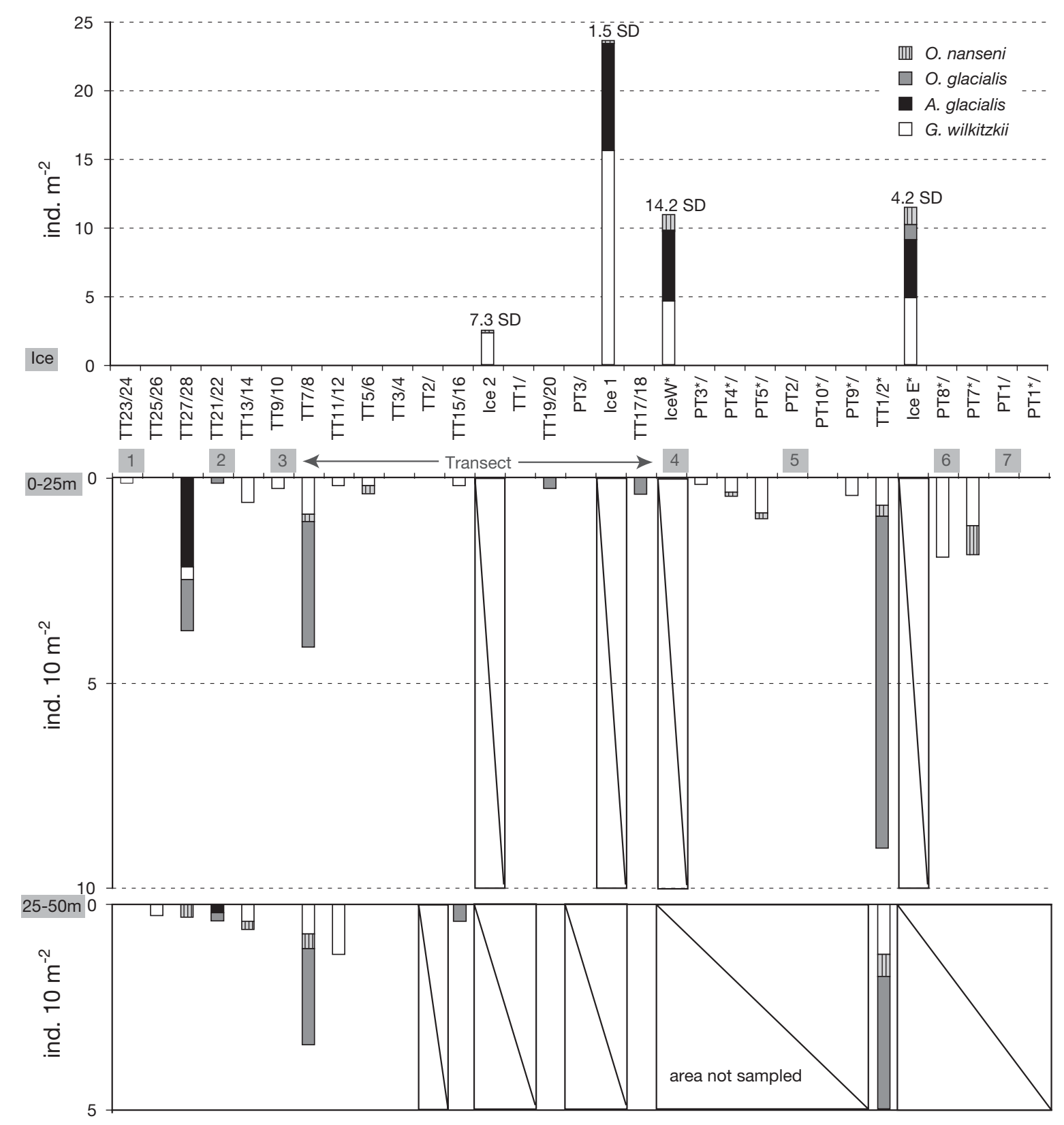

Fig. 3. Abundance (ind. $\mathrm{m}^{-2}$ ) and relative contribution of 4 sympagic amphipod species sampled from ice underside (top graph), surface layer ( 0 to $25 \mathrm{~m}$ ) and 25 to $50 \mathrm{~m}$ (middle and bottom graphs, respectively). White areas with bar were not sampled. SD: standard deviation; station codes and asterisks as in Fig. 1

trawls contained ice fauna. Nearly half of the deep trawls contained no ice amphipods. Most ice amphipods sampled in the water column were close to Stn Ice E in both the shallow and the deep trawls (Stns TT1/2, Transect 5). At this location, compared to under ice numbers total abundance was $10 \%$ lower in the upper water layer and $5 \%$ lower below $25 \mathrm{~m}$ depth. In both trawl hauls, Onisimus glacialis dominated. In contrast, at the nearby trawl station PT9 only solitary specimens of Gammarus wilkitzkii were caught.
Ice amphipods were found in relatively high numbers in the shallow trawls near Belgica Banken (Stn TT 7, Transect 3) and east of Gael Hamkes Bay (Stn TT 27, Transect 1) off the coast of Greenland, approx. 250 nautical miles south of the ice edge.

There were differences in the relative composition of species in the trawl catches compared to those in the ice samples. In the trawls, Onisimus glacialis was the dominant species except for the southernmost trawl station (Stn TT 27, Transect 1), where most specimens 
in the catch belonged to the genus Apherusa. In Hinlopen Strait and its northern extension Questrenna, Gammarus wilkitzkii and $O$. nanseni dominated the pelagic ice fauna catch (Stns PT 7 and PT 8, Transect 6). On Transect 7 into the Kongsfjord (used as a 'reference system') no ice amphipods were found in the pelagic zone.

There were no differences in species abundance between pelagic and Tucker trawl data: ANOVA, $F(3,92)=1.714, p=0.17$. Apherusa glacialis and Onisimus glacialis, the smallest amphipod species (corresponding to maximum body lengths of approx. $14 \mathrm{~mm}$ for both species; Beuchel \& Lønne 2002, Arndt $\&$ Beuchel 2005) were entirely absent from the pelagic trawls (Fig. 4). In pelagic trawls, Gammarus wilkitzkii contributed $94 \%$ to all specimens sampled, whereas in the Tucker trawls this species made up $22 \%$ compared to $69 \%$ for the numerically dominant O. glacialis.

The length distribution of all 4 species caught with the different sampling gears shows that the Tucker trawl covers all size ranges better, and can therefore be considered the more suitable sampling method for small species such as Apherusa glacialis and Onisimus glacialis and small ontogenetic stages (juveniles) than the pelagic trawl (Fig. 4). Juvenile Gammarus wilkitzkii were missing from the pelagic trawl samples, but dominated the total catch in the Tucker trawl samples. The Tucker trawl-catch of this species was also comparable to that of the suction-sampler in terms of sex/ stage distribution: ANOVA, $F(2,66)=2.021, \mathrm{p}=0.141$. The clear dominance of male $G$. wilkitzkii in the water

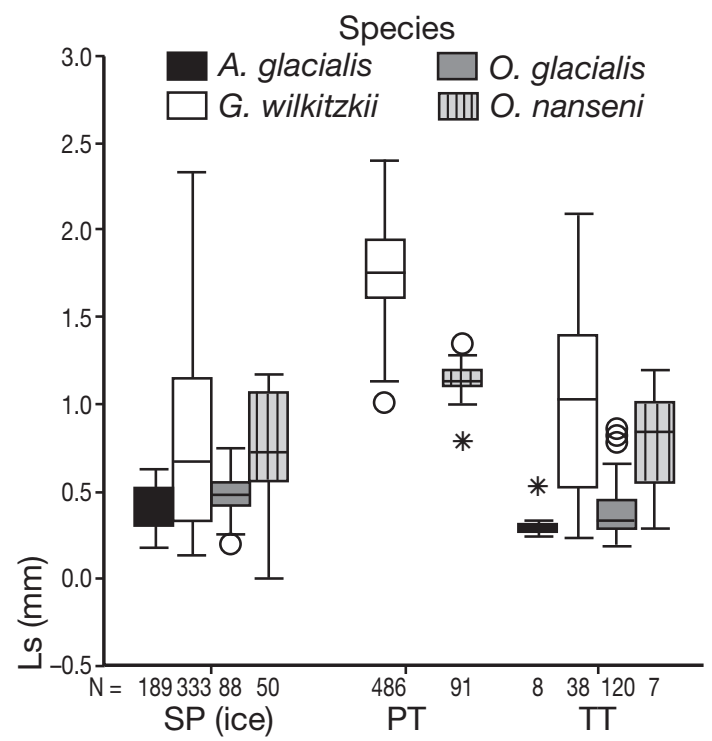

Fig. 4. Length-species selectivity for all 3 sampling techniques applied. SP (ice): suction pump; PT: pelagic trawl; TT: Tucker trawl; Ls: length of 1st pereonal segment; $\mathrm{N}$ : total number of specimens; (O) outliers and (*) extremes column found by Werner et al. (1999) was not apparent in our study.

Comparison of the distribution of the 2 Onisimus species in the different sampling gears revealed that more individuals were present in the pelagic than in the sympagic domain. In contrast to the sea ice results, juveniles represented $70 \%$ of all specimens of Onisimus spp. sampled by Tucker trawl.

\section{Simulated ice drift}

The sea ice sampled in the area north of Svalbard stems from the eastern Arctic. Assuming that the ice investigated had not formed along its drift track, it must have been produced in the Laptev Sea, and is therefore multiyear ice (Fig. 5). The ice sampled in the central Fram Strait also derives from the eastern Arctic. The ice motion simulation suggests that the ice close to Greenland stems from the central and western Arctic. The ice was thicker and older in this area than that sampled in the eastern Fram Strait.

If the sea ice started to melt at the time when air temperatures rose above $0^{\circ} \mathrm{C}$, then the decay of all traced ice patches started in June 2002, 3 to 4 mo prior to sampling (scope in Fig. 5). Overlaying the back trajectories with the period of melting prior to sampling shows that the ice pack at Stn Ice E in particular, but also at Stns Ice $\mathrm{W}$ and Ice 1 maintained a relatively stationary position in the polar waters north of the Fram Strait (approximate drift speed can be withdrawn from the length of the dashed arrows in Fig. 5, with shorter arrows indicating relatively slow drift and long stationary residence, and longer arrows denote longer distances traveled southward within the time frame of the summer melt). In contrast, the ice at Stn TT 7/8 (Transect 3) was formed on the north coast of Alaska, but its drift was probably slowed by the dense ice pack along the Greenland coast.

\section{DISCUSSION}

Along the marginal ice zone, all 4 sympagic amphipod species are released to the water column, with the most likely driving forces being ice breakup and swell along with the structural decay of sea ice during the summer melt. Compared to numbers in the ice, amphipod density was generally low $\left(<5\right.$ ind. $\left.10 \mathrm{~m}^{-2}\right)$ in the underlying and adjacent waters but highest numbers were found (1) within the $200 \mathrm{~m}$ isobaths on the East Greenland Shelf, (2) in the ice fringe north of Svalbard and (3) in the strait east of Spitsbergen (Hinlopen Strait). Within the water column, the distribution of amphipods showed large spatial patchiness in the 


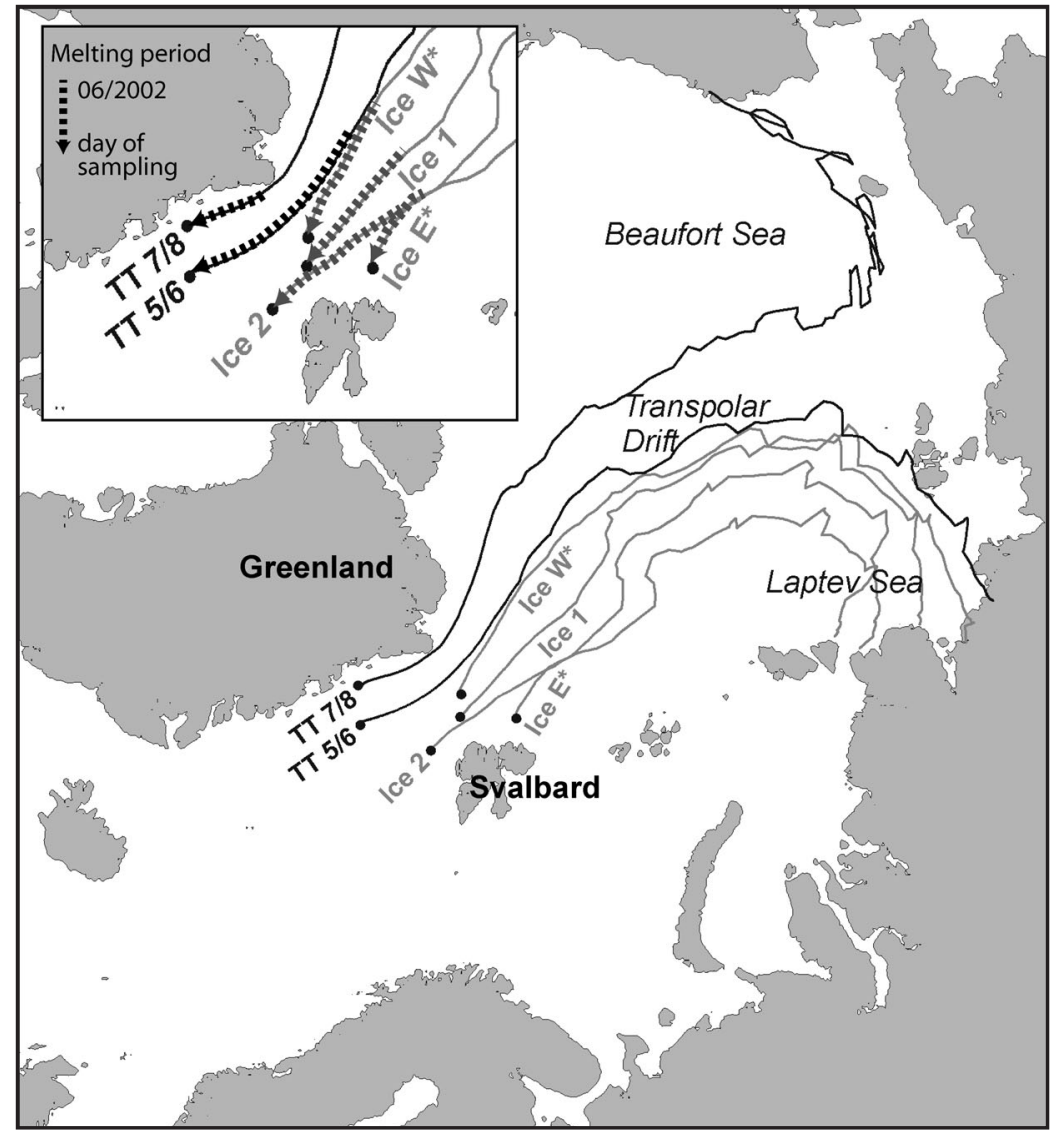

Fig. 5. Simulated back trajectories (gray lines) of the 4 ice floes examined and ice border position (black lines) next to 2 Tucker trawls stations in western Fram Strait. Scope: melting period for the summer months prior to sampling (according to NCAR). Station codes and asterisks as in Fig. 1

bution. Spatial heterogeneity and variability in species composition and abundance of sympagic organisms have been quantified using upward directed sonar (Hop et al. 2000). The high standard deviations in Fig. 3 (top graph) illustrate the high variability among subsamples taken from each ice floe. Patches of dense fauna often alternate with patches of no fauna at all. Heterogeneity in the ice ecosystem should increase when species are disgorged into the pelagic realm.

\section{Ecosystem disruption and mechanisms of release of ice organisms}

Physical properties indicated persistent melting at all 4 ice stations (see 'Materials and methods'). The successive decay of sea ice does not initiate a sudden pulse of ice organisms, but strong wave and swell action such as that caused by storms does (C. Arndt pers. obs.). Both the Polar Front and the marginal ice zone represent frontal systems. The interaction of ice cover and regional current fields generate heterogeneous patterns on different scales (Barry \& Dayton 1991): horizontal and vertical advective processes, eddies and meanders (Manley et al. 1986,

vertical and horizontal dimension. Heterogeneity is a common feature in marine systems, resulting in distributions that appear arbitrary and random (Barry \& Dayton 1991, Kolosa \& Rollo 1991). Also in sea ice, biotic heterogeneity has been identified in a number of studies (e.g. Pike \& Welch 1990, Poltermann 1997 , Swadling et al. 1997, Hop et al. 2000). Environmental constraints under the deeper Arctic ice pack are considered constant (Maykut 1985). It can be assumed that biological (rather than physical) processes govern heterogeneity here. Towards the ice margin, hydrodynamic processes gain importance and determine the distribution of ice amphipods in space and time, similar to observations in the pelagic environment (Barry \& Dayton 1991).

Sea ice comprises a complex 3-dimensional system with plane surfaces, pressure ridges, caverns and domes (Poltermann 1997, Hop et al. 2000). Structural changes directly affect the ice community. For instance, freezemelt and deformation events alter the quality of the substratum and create protected areas. In motile species food availability and shelter determine their distri-
Johannessen et al. 1994, Nøst \& Dybesland 1997). The CTD sections presented in this study (Fig. 2) reveal large vertical displacement of isopycnals and isotherms, indicating the existence of mesoscale hydrographic features and frontal systems. Bathymetry (fjord/strait systems, shelf breaks, sea mountains) alters current speed and direction of overlying water masses. Additionally, very powerful hydrodynamic features are wind generated waves and swell, since these break the ice pack into smaller pieces and cause continuous flushing of the ice. Oceanographers often report the analogy of moving water parcels. An organism, released from the ice to the water column will be subject to the physical constraints of the water body it enters. Biological interactions, such as an organism's mobility may be negligible in the case of ice amphipods, since their swimming capacity is limited to short distances (Lønne \& Gulliksen 1991a). Being adapted to an 'upside-down benthic habitat' (Mohr \& Tibbs 1963) released ice amphipods will eventually sink through the water column. Sinking with continuous speed and unaffected by water movements, a specimen of 
Onisimus glacialis would reach the sea bottom at $100 \mathrm{~m}$ in approximately $80 \mathrm{~min}$ (Fig. 6A). With an (on average) higher mass and body volume, a specimen of Gammarus wilkitzkii would need only half this time to arrive at the same depth. As sinking rate is a function of the density of an organism and the density of the medium, sinking velocities are slightly higher in melt water than in more saline water (Fig. 6B). In contrast to its relatively high abundance in the pelagic, $O$. glacialis comprises a minority in the ice community (Fig. 3). The high relative proportion of this species in the pelagic may be attributable to its slower sinking rate. Another possible reason could be that this species is the first to be swept off the ice substrate. In contrast, the spiny morphology and the dorsolateral position of the pereiopods allow G. wilkitzkii to hold firmly to sea ice (Poltermann 1997); its presence at the southernmost tip of the ice tongue in October (Stn Ice 1) underscores its site fidelity even under rough conditions. In nature, sinking of immobile particles or organisms with limited mobility such as sympagic amphipods is not directly vertical, but erratic due to the hydrodynamic processes involved.

Despite the 3 to 4 mo melting conditions prior to sampling, the ice ecosystem at Stns Ice W and Ice 1 was probably relatively unaffected by disruptive processes. In contrast to the hydrographic forces that act along the marginal ice zone, melting as such is not considered the initial cause of loss of ice fauna. Since melting is a relatively slow process, it may enable the gradual migration
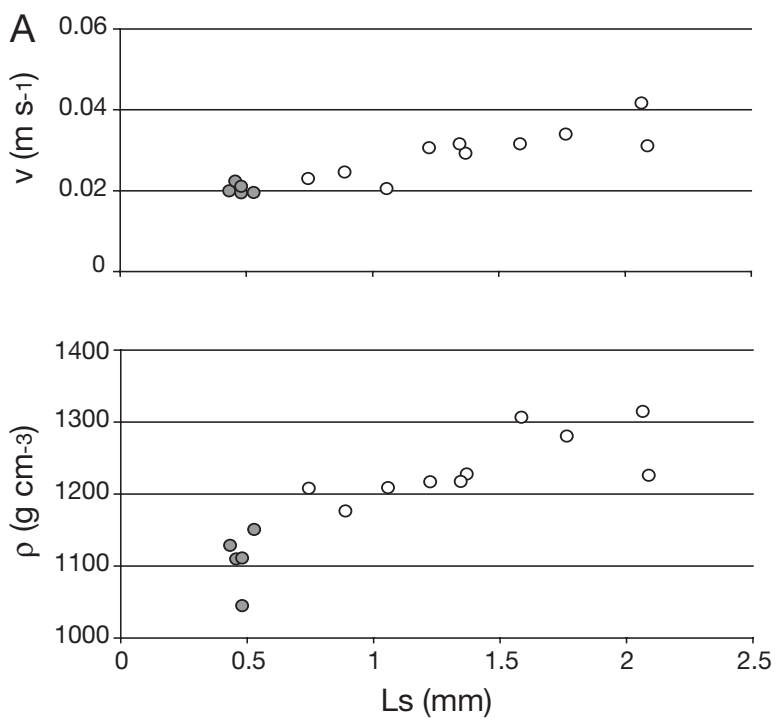

of ice amphipods into the deeper ice pack in search of better conditions (B. Gulliksen pers. obs.). As mentioned earlier, dynamic forces (such as those along the marginal ice zone) are likely to initiate and accelerate the release of ice organisms. Weekly averaged ice velocity vectors (NSIDC) showed no or relatively slow ice motion in the Fram Strait and Svalbard area during the entire summer period (June to September; Fig. 5). Ice drift velocities ranged between 0 and a maximum of $3 \mathrm{~cm} \mathrm{~s}^{-1}$ and followed meso-scale, erratic patterns, indicating stable and (in relation to the ice ecosystem) undisturbed conditions. Wave and swell action can be assumed to have been negligible for the entire period. A sudden increase in drift speed was recorded prior to sampling in October, with speeds of up to $10 \mathrm{~cm} \mathrm{~s}^{-1}$. The low abundance of ice amphipods at Stn Ice 2 may support the hypothesis of mechanic (rather than thermodynamic) processes causing the loss of ice fauna.

\section{Localization of pelagic occurrence and settling of sympagic amphipods}

Our results indicate that it is difficult to relate abundance of sympagic amphipods in the sympagic to their abundance in the nearby pelagic environment, or their abundance in deeper waters to that in surface layers (Fig. 3). Different hydrographic features prevail at different water depths, and pelagic predators prey on sinking organic matter.

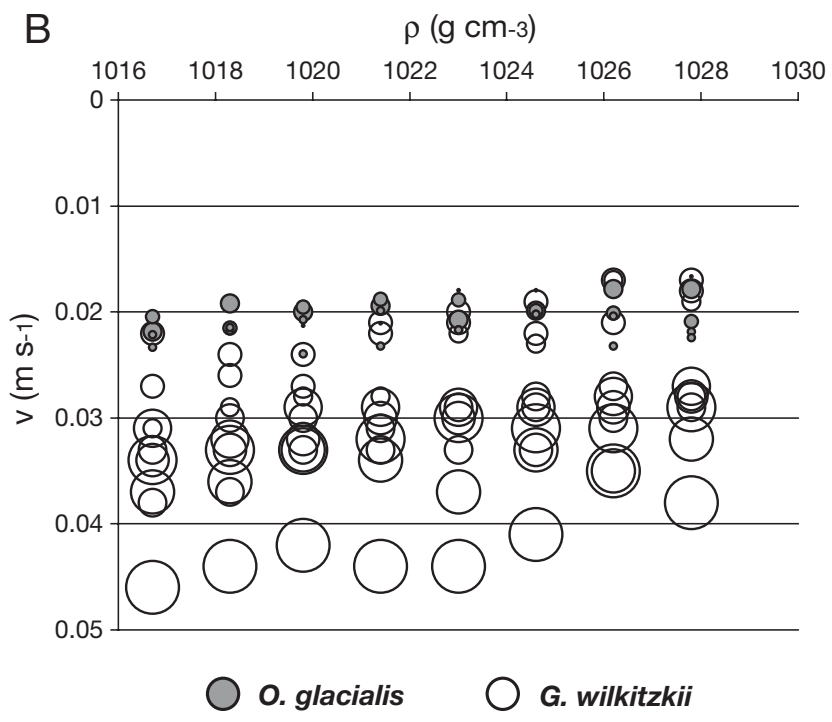

Fig. 6. Gammarus wilkitzkii and Onisimus glacialis. (A) Relationship of length of 1st pereonal segment (Ls), individual body density $(\rho)$ and sinking velocity (v) averaged for different densities of water (corresponding to salinities of 21 to 35 at $4{ }^{\circ} \mathrm{C}$ ) for 5 individuals of $O$. glacialis and 10 individuals of $G$. wilkitzkii; test specimens were anaesthetized to prevent them from swimming; body volume was determined using a glass burette similar to that designed by Langvatn (1972). (B) Sinking velocity, showing variation as a function of ambient density (salinity) and individual body density, illustrated by relative bubble size: average length $(\mathrm{Ls})=0.47 \pm 0.04 \mathrm{~mm}$, and average density $(\rho)=1109.19 \pm 39.61 \mathrm{~g} \mathrm{~cm}^{-3}$ for $O$. glacialis; Ls $=1.41 \pm 0.46 \mathrm{~mm}$ and $\rho=1238.45 \pm$ $46.10 \mathrm{~g} \mathrm{~cm}^{-3}$ for G. wilkitzkii 
It is apparent from our study that not the deep sea beneath the permanent ice cover benefits from precipitating material, but rather the shelf areas beneath the periodically retreating ice pack. Relatively high current speeds advect ice-derived particles over large distances (e.g. the speed of the Transpolar Drift Stream is 4 to $8 \mathrm{~km} \mathrm{~d}^{-1}$ in the summer period; Barry et al. 1993). In contrast, coastal areas are often characterized by reduced current speed, and fjords and bays provide calm zones and local circulation systems. Released ice amphipods are capable of surviving in shallow coastal areas (Arndt et al. 2005b). We define shallow benthic areas (such as those found nearshore) as 'retention areas' that serve as temporary habitats for sympagic organisms during ice free periods and as stepping stones for recolonization of the ice substrate during periods of ice coverage (Arndt et al. 2005b).

Pelagic occurrence of the sympagic amphipod Gammarus wilkitzkii has been observed earlier in Hinlopen Strait (Transect 6) and in fjords on the north and east coasts of Svalbard in waters down to $200 \mathrm{~m}$ (C. Arndt pers. obs.). This species has also been sampled in the North Atlantic (Steele \& Steele 1974) and in the water column off the E Greenland coast (Werner et al. 1999). Ice fauna released to the East Greenland Current may act as sympago-benthic couplers (Arndt et al. 2005b) when advected to shallow coastal waters. The bulk, however, will be lost from the ice ecosystem. The annual loss of sympagic fauna in this area due to the Fram Strait ice export has been recently estimated to be in the order of $38 \times 10^{5} \mathrm{t}$ wet mass (Arndt \& Lønne 2002). This organic input fuels the pelagic and benthic realms.

\section{Climatic cycling and loss of sympagic fauna}

Based on quantitative studies in the late 1980s and early 1990s, Lønne \& Gulliksen (1991b) assumed an average biomass of $5 \mathrm{~g}$ wet mass $\mathrm{m}^{-2}$ sea ice for the area north of Svalbard. Interpolated biomass values based on all available data sets combined resulted in comparable numbers (5 to $6 \mathrm{~g}$ wet mass $\mathrm{m}^{-2}$ ) for the same area, but were to a large extent biased by the high values in 1991 (Arndt \& Lønne 2002). In contrast, biomass values recorded in recent years were almost 10 times lower in the multiyear ice pack of this region, reaching a record low in the year 2002 (Fig. 7). It is unclear from where the ice sampled in previous years originated, but we have estimated the history of the ice patches investigated in this study by simulated trajectories (Fig. 5). Most ice entering the Fram Strait in September 2002 stemmed from the ice formation areas in the Laptev Sea and was assumed to be between 2 and $3 \mathrm{yr}$ old; sea ice that has its origin in the western Beaufort Sea needs at least 6 yr for its transpolar drift towards Fram Strait (Rigor et al. 2002). It has been shown by Arndt \& Lønne (2002) that origin and drift history of sea ice to a large extent determine species composition and degree of 'maturation' of the ice ecosystem. Colonization of new sea ice is time dependent and, considering the different life history traits of ice amphipods (Beuchel \& Lønne 2002, Arndt \& Beuchel 2005), the sympagic ecosystem needs time to become established, with 2 to $3 \mathrm{yr}$ old ice still in the developing process (Arndt \& Lønne 2002). Our analysis of population structure shows a more biased distribution towards smaller size classes for the dominating species Gammarus wilkitzkii (Fig. 3).

One reason for the comparatively low abundance and biomass values found in recent years (Fig. 7) could be attributable to the prevailing climatic regime (Rigor et al. 2002): a positive Arctic Oscillation index drives a high proportion of young ice from the eastern Arctic towards the Svalbard area and promotes ice divergence. Sampling between 1998 and 2002 occurred in the transition period from high-index to low-index years (Rigor et al. 2002) but, at least for the year 2002, Serreze et al. (2003) observed a notable ice divergence. The climatic regime in the 1980s favored the export of thick multiyear ice from the central Arctic and converging ice motion. Sampling in the area north
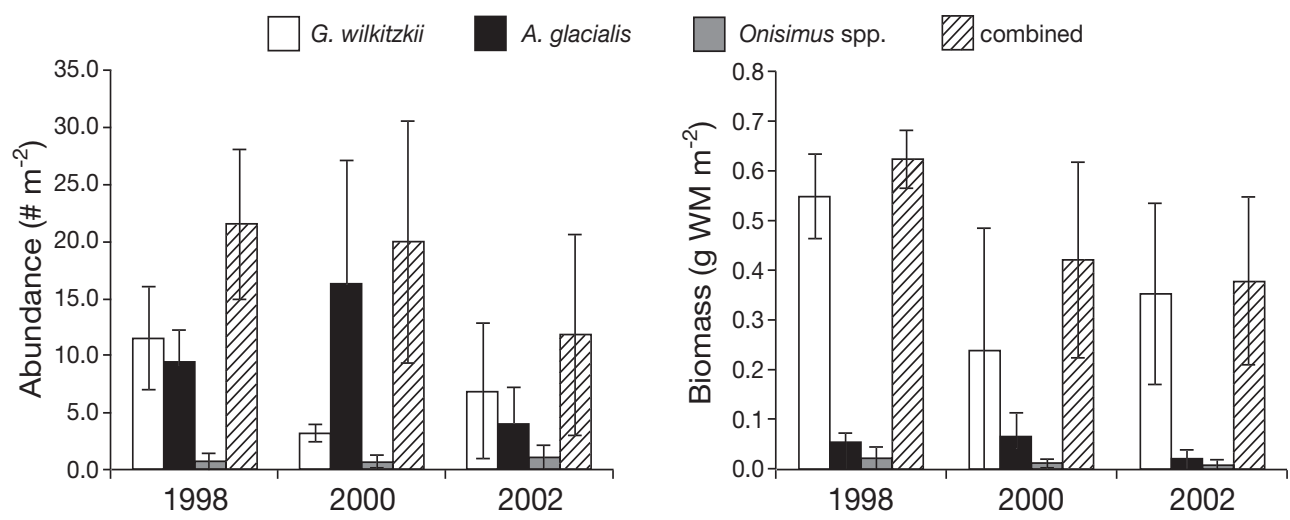

Fig. 7. Comparison of mean ( $\pm \mathrm{SD}$ ) composition, abundance (ind. $\mathrm{m}^{-2}$ ) and biomass (g wet mass [WM] m ${ }^{-2}$ ) for sympagic macrofauna sampled in the multiyear ice pack north of Svalbard in September 1998 (Beuchel et al. 1998), 2000 (UNIS unpubl. report) and 2002 (this study). Number of stations were 3 in 1998 and 2000, 4 in 2002 
of Svalbard during that period may have been conducted in very old ice, which stemmed from the central and western Arctic. If this is true, then geographic differences in the ice community data can be correlated with the climatic cycle. Not only origin and age but also ice history have a considerable impact on the sympagic community. A high proportion of young ice would explain the depauperate sympagic community. In addition, a predominantly diverging ice motion leads to more open water within the ice pack and as a consequence, to easy breakup, swell and decay. Such environmental circumstances should be unfavorable for the establishment of the sympagic ecosystem. In this scenario of a discontinuous ice pack of reduced extent, release of ice fauna may occur in areas north of the Polar Front. Marine life on shelf areas will thus be disadvantaged by the precipitation of ice-derived organic material over deep water. We conclude that earlier calculations on the loss of ice-bound bio-energy in the Fram Strait and Svalbard area (Lønne \& Gulliksen 1991b, Arndt \& Lønne 2002) may have been overestimations or apply only to certain climatic regimes.

Acknowledgement. We are grateful for support by the cruise leaders B. Gulliksen and T. Haug and the crew of RV 'Jan Mayen', P. Kuklinski and all the other divers, the University Centre on Svalbard and Total E \& P. Special thanks go to O. J. Lønne and 3 anonymous reviewers for their valuable comments on this manuscript.

\section{LITERATURE CITED}

Aagaard K, Swift JH, Carmack EC (1985) Thermohaline circulation in the Arctic mediterranean seas. J Geophys Res 90:4833-4846

Aarset AV (1992) The ecophysiology of under-ice fauna. $\mathrm{PhD}$ dissertation, University of Trondheim

Arndt CE, Beuchel F (2005) Life cycle and population dynamics of the Arctic sympagic amphipods Onisimus nanseni SARS and O. glacialis SARS (Gammaridea: Lysianassidae). Polar Biol (in press)

Arndt CE, Lønne OJ (2002) Transport of bioenergy by large scale Arctic ice drift. In: Squire V, Langhorne P (eds) Ice in the environment. Proc 16th IAHR Int Symp Ice, Dunedin, p 382-390

Arndt CE, Berge J, Brandt A (2005a) Mouthpart-atlas of arctic sympagic amphipods - trophic niche separation based on mouthpart morphology and feeding ecology. J Crustac Biol 25(3):401-412

Arndt CE, Fernandez-Leborans G, Seuthe L, Berge J, Gulliksen B (2005b) Ciliated epibionts on the Arctic amphipod Gammarus wilkitzkii as indicators for sympago-benthic coupling. Mar Biol (in press)

Barry JP, Dayton PK (1991) Physical heterogeneity and the organization of marine communities. In: Kolosa J, Pickett STA (eds) Ecological heterogeneity. Springer-Verlag, New York, p 270-320

Barry RG, Serreze MC, Maslanik JA, Preller RH (1993) The Arctic sea ice-climate system: observations and modeling. Rev Geophys 31:397-422
Beuchel F, Lønne OJ (2002) Population dynamics of the sympagic amphipods Gammarus wilkitzkii and Apherusa glacialis in sea ice north of Svalbard. Polar Biol 25:241-250

Beuchel F, Borgå K, Karlsson S, Lilleøkdal G (1998) Distribution of the sympagic fauna at 3 different locations north of Svalbard. In: Lønne OJ (ed) Reports of the AB-310 course at UNIS, September 1998, University Centre on Svalbard, p 1-14 (also available at www.unis.no)

Bradstreet MSW, Cross WE (1982) Trophic relationships at high Arctic ice edges. Arctic 35:1-12

George RY, Paul AZ (1970) USC-FSU-biological investigations from the Fletcher's ice island T-3 on deep-sea and under-ice benthos of the Arctic Ocean. Report No. 1, University of South California, Los Angeles, CA

Gradinger R (1996) Climate change and biological oceanography of the Arctic Ocean. In: Wadham P, Dowdeswell JA, Schofield AN (eds) The Arctic and environmental change. Gordon \& Breach, Amsterdam, p 77-86

Gradinger R, Friedrich C, Spindler M (1999) Abundance, biomass and composition of the sea ice biota of the Greenland Sea pack ice. Deep-Sea Res II 46:1457-1472

Gulliksen B, Lønne OJ (1989) Distribution, abundance, and ecological importance of marine sympagic fauna in the Arctic. Rapp P-V Réun Cons Int Explor Mar 188:133-138

Hop H, Poltermann M, Lønne OJ, Falk-Petersen S, Korsnes R, Budgell WP (2000) Ice amphipod distribution relative to ice density and under-ice topography in the northern Barents Sea. Polar Biol 23:357-367

Johannessen OM, Sandven S, Budgell WP, Johannessen JA, Shuman RA (1994) Observation and simulation of ice tongues and vortex pairs in the marginal ice zone. Geophys Monogr 85:109-136

Kolosa J, Rollo CD (1991) Introduction: the heterogeneity of heterogeneity: a glossary. In: Kolosa J, Pickett STA (eds) Ecological heterogeneity. Springer-Verlag, New York, p 1-23

Langvatn R (1972) Field measurement of the volume of small mammal organs. Oikos 23:142-144

Lønne OJ, Gulliksen B (1991a) On the distribution of sympagic macro-fauna in the seasonally ice covered Barents Sea. Polar Biol 11:457-469

Lønne OJ, Gulliksen B (1991b) Sympagic macro-fauna from multiyear sea-ice near Svalbard. Polar Biol 11:471-477

Manley TO, Villanueva JZ, Gascard JC, Jeannin PF, Hunkins KL, Van Leer J (1986) Mesoscale oceanographic processes beneath the ice of Fram Strait. Science 236:432-236

Maykut GA (1985) An introduction to ice in the polar oceans. Department of Atmospheric Science, University of Washington, Seattle, WA

Melnikov IA (1997) The Arctic sea ice ecosystem. Gordon \& Breach, Amsterdam

Melnikov IA, Kolosova EG, Welch HE, Zhitina LS (2002) Sea ice biological communities and nutrient dynamics in the Canada Basin of the Arctic Ocean. Deep-Sea Res I 49: 1623-1649

Mohr JL, Tibbs J (1963) Ecology of ice substrates. In: Arctic Institute of North America, Alaska, Proc of Arctic Basin Symp Oct 1962, p 245-248

Nøst E, Dybesland E (1997) Review of sea ice drift and distribution in the Fram Strait 1972-1994. Report No. 98. Norwegian Polar Institute, Oslo

Pavlov V, Pavlova O, Korsnes R (2004) Sea ice fluxes and drift trajectories from potential pollution sources, computed with a statistical sea ice model of the Arctic Ocean. J Mar Syst 48:133-157

Peinert R, Antia A, Bauernfeind E, von Bodungen B and 6 others (2001a) Particle flux variability in the polar and 
Atlantic biogeochemical provinces of the Nordic Seas. In: Schäfer P, Ritzrau W, Schlüter $M$, Thiede J (eds) The northern North Atlantic. Springer-Verlag, Berlin, p 53-68

Peinert R, Bauernfeind E, Gradinger R, Haupt O, Krumbholz M, Peeken I, Werner I, Zeitzschel B (2001b) Biogenic particle sources and vertical flux patterns in the seasonally ice-covered Greenland Sea. In: Schäfer P, Ritzrau W, Schlüter M, Thiede J (eds) The northern North Atlantic. Springer-Verlag, Berlin, p 69-79

Pike DG, Welch HE (1990) Spatial and temporal distribution of sub-ice macrofauna in the Barrow Strait area, Northwest Territories. Can J Fish Aquat Sci 47:81-91

Poltermann M (1997) Biologische und ökologische Untersuchungen zur kryopelagischen Amphipodenfauna des arktischen Meereises. Ber Polarforsch 225:170

Poltermann M (1998) Abundance, biomass and small-scale distribution of cryopelagic amphipods in the Franz Josef Land area (Arctic). Polar Biol 20:134-138

Poltermann M (2001) Arctic sea ice as feeding ground for amphipods-food sources and strategies. Polar Biol 24: 89-96

Poltermann M, Hop H, Falk-Petersen S (2000) Life under Arctic sea ice-reproduction strategies of 2 sympagic (iceassociated) amphipod species, Gammarus wilkitzkii and Apherusa glacialis. Mar Biol 136:913-920

Ramseier RO, Garrity C, Martin T (2001) An overview of seaice conditions in the Greenland Sea and the relationship of oceanic sedimentation to the ice regime. In: Schäfer $\mathrm{P}$, Ritzrau W, Schlüter M, Thiede J (eds) The northern North Atlantic. Springer-Verlag, Berlin, p 53-68

Rigor IG, Wallace JM, Colony RL (2002) On the response of sea ice to the Arctic Oscillation. J Climate 15:2648-2668

Editorial responsibility: Otto Kinne (Editor-in-Chief), Oldendorf/Luhe, Germany
Schäfer P, Thiede J, Gerlach S, Graf G, Suess E, Zeitzschel B (2001) The environment of the northern North-Atlantic Ocean: modern depositional processes and their historical documentation. In: Schäfer P, Ritzrau W, Schlüter $M$, Thiede J (eds) The northern North Atlantic. SpringerVerlag, Berlin, p 1-17

Scott CL, Falk-Petersen S, Sargent JR, Hop H, Lønne OJ, Poltermann M (1999) Lipids and trophic interactions of ice fauna and pelagic zooplankton in the marginal ice zone of the Barents Sea. Polar Biol 21:65-70

Serreze MC, Maslanik JA, Scambos TA, Fetterer F and 6 others (2003) A record minimum arctic sea ice extent and area in 2002. Geophys Res Lett 30:10.11-10.14

Steele DH, Steele VJ (1974) The biology of Gammarus (Crustacea, Amphipoda) in the northwestern Atlantic. VIII. Geographic distribution of the northern species. Can J Zool 52:1115-1120

Swadling KM, Gibson JAE, Ritz DA, Nichols PD (1997) Horizontal patchiness in sympagic organisms of the Antarctic fast ice. Antarct Sci 9:399-406

Thomas D, Martin S, Rothrock D, Steele M (1996) Assimilating satellite concentration data into an Arctic sea ice mass balance model, 1979-1985. J Geophys Res 101: 20849-20868

Vinje T (2001) Fram Strait ice fluxes and atmospheric circulation: 1950-2000. J Climate 14:3508-3517

Wadhams P (2000) Ice in the ocean. Gordon \& Breach, Amsterdam

Werner I, Auel H, Garrity C, Hagen W (1999) Pelagic occurrence of the sympagic amphipod Gammarus wilkitzkii in ice-free waters of the Greenland Sea - dead end or part of life-cycle? Polar Biol 22:56-60

Submitted: July 26, 2004; Accepted: February 10, 2005

Proofs received from author(s): September 5, 2005 